\title{
Host Range of the Coral-Associated Worm Snail Petaloconchus sp. (Gastropoda: Vermetidae), a Newly Discovered Cryptogenic Pest Species in the Southern Caribbean
}

\author{
Bert W. Hoeksema 1,2,3,*iD, Charlotte E. Harper 1,2 ${ }^{\mathbb{D}}$, Sean J. Langdon-Down 1,2 $\mathbb{D}$, Roel J. van der Schoot ${ }^{1,2} \mathbb{D}$, \\ Annabel Smith-Moorhouse ${ }^{1,2} \mathbb{D}$, Roselle Spaargaren ${ }^{1,2} \mathbb{D}$ and Rosalie F. Timmerman ${ }^{1,2} \mathbb{D}$ \\ 1 Taxonomy, Systematics and Geodiversity Group, Naturalis Biodiversity Center, P.O. Box 9517, \\ 2300 RA Leiden, The Netherlands; c.harper@student.rug.nl (C.E.H.); \\ s.langdon-down@student.rug.nl (S.J.L.-D.); roel.vanderschoot@naturalis.nl (R.J.v.d.S.); \\ a.smith-moorhouse@student.rug.nl (A.S.-M.); r.spaargaren@student.rug.nl (R.S.); \\ r.f.timmerman@student.rug.nl (R.F.T.) \\ 2 Groningen Institute for Evolutionary Life Sciences, University of Groningen, P.O. Box 11103, \\ 9700 CC Groningen, The Netherlands \\ 3 Institute of Biology Leiden, Leiden University, P.O. Box 9505, 2300 RA Leiden, The Netherlands \\ * Correspondence: bert.hoeksema@naturalis.nl
}

Citation: Hoeksema, B.W.; Harper, C.E.; Langdon-Down, S.J.; van der Schoot, R.J.; Smith-Moorhouse, A.; Spaargaren, R.; Timmerman, R.F. Host Range of the Coral-Associated Worm Snail Petaloconchus sp. (Gastropoda: Vermetidae), a Newly Discovered Cryptogenic Pest Species in the Southern Caribbean. Diversity 2022, 14, 196. https://doi.org/ $10.3390 / \mathrm{d} 14030196$

Academic Editor: Savvas Genitsaris

Received: 18 February 2022

Accepted: 4 March 2022

Published: 7 March 2022

Publisher's Note: MDPI stays neutral with regard to jurisdictional claims in published maps and institutional affiliations.

Copyright: (C) 2022 by the authors. Licensee MDPI, Basel, Switzerland. This article is an open access article distributed under the terms and conditions of the Creative Commons Attribution (CC BY) license (https:// creativecommons.org/licenses/by/ $4.0 /)$.

\begin{abstract}
The presence of associated endofauna can have an impact on the health of corals. During fieldwork on the southern Caribbean island of Curaçao in 2021, the presence of an unknown coraldwelling worm snail was discovered, which appeared to cause damage to its hosts. A study of photo archives revealed that the species was already present during earlier surveys at Curaçao since 2014 and also in the southern Caribbean island of Bonaire in 2019. It was not found in St. Eustatius, an island in the eastern Caribbean, during an expedition in 2015. The vermetid snail was preliminarily identified as Petaloconchus sp. Its habitat choice resembles that of P. keenae, a West Pacific coral symbiont. The Caribbean species was observed in 21 host coral species, more than reported for any other vermetid. Because Petaloconchus sp. is a habitat generalist, it is possible that it was introduced from an area with another host-coral fauna. The unknown vermetid is considered to be cryptogenic until future studies reveal its actual identity and its native range.
\end{abstract}

Keywords: coral damage; coral reef; host generalist; Millepora; scleractinia

\section{Introduction}

Worm snails of the family Vermetidae are common inhabitants of coral reefs and rocky shores in tropical to warm-temperate marine coastal waters, where they live embedded in dead or live corals or attached to other hard substrata [1]. They have tube-shaped shells, mostly without the regular shell coiling [2,3], which in some species form dense, reef-building aggregations [4-6]. Because of their reef-building capacity in the intertidal or immediate subtidal zone, they play an important role as sea-level and sea-surface temperature indicators in the fossil record [6-8]. The history of Vermetidae systematics is complex, which is partly due to the confusion of their calcareous tubes with those of other organisms, such as serpulid worms [9].

Although there is much literature on coral-associated fauna in the Caribbean, vermetid snails are usually not included [10-13]. Apparently, all host-related information on coral-associated vermetids is from the Indo-Pacific, predominantly involving Ceraesignum maximum (G.B. Sowerby I, 1825), previously known as Dendropoma maxima, which dwells on scleractinians, blue corals, and fire corals [14-16]. This species is notorious because of its harmful effect on the growth, survival, and photophysiology of host corals [17-20]. There are only a few other coral-vermetid records from the Indo-Pacific, including Petaloconchus 
keenae Hadfield \& Kay, 1972 near Hawaii [21], Thylacodes hadfieldi (W.C. Kelly, 2007) near Guam [22], and Thylacodes spp. off the west coast of India [23].

During a recent survey of the coral-associated fauna of Curaçao, coral-dwelling worm snails were discovered for the first time in the Caribbean. In order to investigate their preferred habitats, all observed host coral species were recorded. Because the species appears to be cryptogenic, we discuss why no earlier records are known for the Caribbean. The present report serves to create awareness for this cryptogenic species for future research on its origin and its possible effect on the health of Caribbean coral reefs.

\section{Materials and Methods}

The survey of coral-associated fauna took place during October-December 2021 along the leeward side of the island of Curaçao. Because the coral-dwelling vermetid was not recorded before in the Caribbean and was overlooked by the first author during earlier surveys, his photo archive was checked for the presence of this snail during fieldwork at Curaçao in 2017, 2015, and 2014, Bonaire in 2019, and St. Eustatius in 2015. Curaçao and Bonaire are located in the southern Caribbean and St. Eustatius in the eastern Caribbean (Figure 1). All association records were listed per island and year (Table 1). Photographic evidence (showing a shell with the operculum present) is presented for each host (Supplementary Materials).

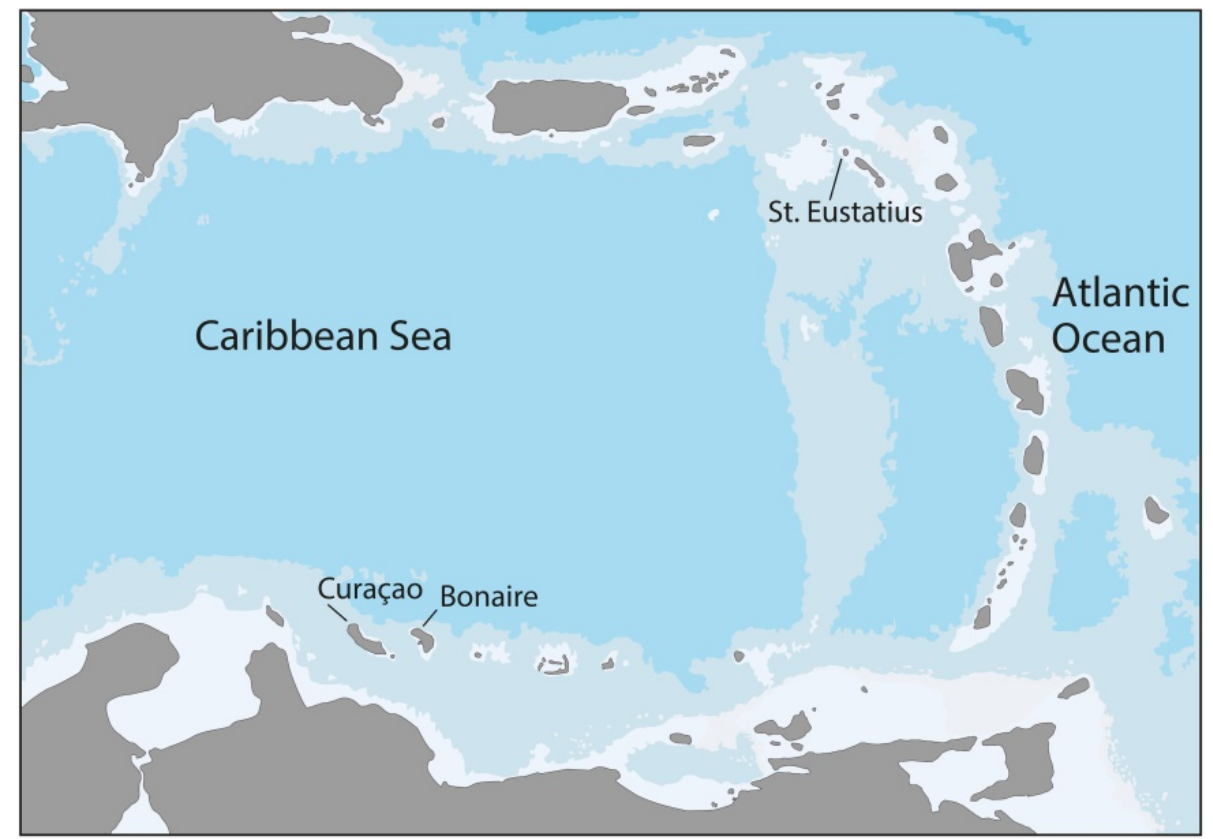

Figure 1. Map of the eastern part of the Caribbean showing the position of Curaçao, Bonaire and St. Eustatius, where the occurrence of coral-dwelling vermetids was investigated.

\section{Results}

A total of 21 host-coral species-19 scleractinians (Anthozoa) and two milleporids (Hydrozoa)-were recorded, divided over 11 families and 14 genera (Table 1). A few worm snail specimens were found on dead unidentified coral. All records were from the southern Caribbean islands Bonaire and Curaçao, with none from St. Eustatius in the eastern Caribbean. The worm snails with a clearly visible operculum were identified as Petaloconchus sp. (Figures 2 and 3; Supplementary Materials Figures S1-S23). Its operculum has upward-folded margins, giving it a tapering appearance, and its diameter was smaller than that of the shells' aperture, which prevented a total shutting of the tube (Figure 3). A small, concave operculum is characteristic for the genus Petaloconchus H.C. Lea, 1843 [24]. 
Table 1. Records of stony corals as host species (by family) for the vermetid gastropod Petaloconchus sp. based on photographs made at Curaçao (a: 2021; b: 2017; c: 2015; d: 2014), Bonaire (e: 2019), and St. Eustatius (2015).

\begin{tabular}{|c|c|c|c|}
\hline Host Species & Curaçao & Bonaire & St. Eustatius \\
\hline \multicolumn{4}{|l|}{ Anthozoa: Scleractinia } \\
\hline Agariciidae & & & \\
\hline Agaricia agaricites (Linnaeus, 1758) & a & e & - \\
\hline Agaricia humilis (Verrill, 1901) & a & - & - \\
\hline $\begin{array}{l}\text { Agaricia lamarcki Milne Edwards \& Haime, } \\
1851\end{array}$ & a & - & - \\
\hline Astrocoeniidae & & & \\
\hline Stephanocoenia intersepta (Esper, 1795) & a & - & - \\
\hline Dendrophylliidae & & & \\
\hline $\begin{array}{c}\text { Cladopsammia manuelensis (Chevalier, 1966) } \\
\text { Faviidae }\end{array}$ & $\mathrm{b}$ & - & - \\
\hline Colpophyllia natans (Houttuyn, 1772) & a & - & - \\
\hline Diploria labyrinthiformis (Linnaeus, 1758) & a & - & - \\
\hline $\begin{array}{c}\text { Pseudodiploria strigosa (Dana, 1846) } \\
\text { Meandrinidae }\end{array}$ & $\mathrm{a}, \mathrm{d}$ & - & - \\
\hline Eusmilia fastigiata (Pallas, 1766) & $\mathrm{d}$ & - & - \\
\hline $\begin{array}{c}\text { Meandrina meandrites (Linnaeus, 1758) } \\
\text { Merulinidae }\end{array}$ & a & - & - \\
\hline Orbicella annularis (Ellis \& Solander, 1786) & a & e & - \\
\hline Orbicella faveolata (Ellis \& Solander, 1786) & a & - & - \\
\hline $\begin{array}{l}\text { Orbicella franksi (Gregory, 1895) } \\
\text { Montastraeidae }\end{array}$ & a & e & - \\
\hline $\begin{array}{c}\text { Montastraea cavernosa (Linnaeus, 1767) } \\
\text { Pocilloporidae }\end{array}$ & a & e & - \\
\hline $\begin{array}{c}\text { Madracis auretenra Locke, Weil \& Coates, } \\
2007\end{array}$ & a & - & - \\
\hline Madracis decactis (Lyman, 1859) & $\mathrm{d}$ & e & - \\
\hline $\begin{array}{c}\text { Madracis senaria Wells, } 1973 \\
\text { Poritidae }\end{array}$ & a & e & - \\
\hline $\begin{array}{c}\text { Porites astreoides Lamarck, } 1816 \\
\text { Rhizangiidae }\end{array}$ & $a, b$ & $\mathrm{e}$ & - \\
\hline $\begin{array}{c}\text { Siderastrea siderea (Ellis \& Solander, 1768) } \\
\text { Hydrozoa } \\
\text { Milleporidae }\end{array}$ & a & - & - \\
\hline Millepora alcicornis Linnaeus, 1758 & a & - & - \\
\hline Millepora complanata Lamarck, 1816 & $\mathrm{a}, \mathrm{c}$ & - & - \\
\hline Unidentified dead coral & $\mathrm{a}$ & - & - \\
\hline
\end{tabular}

Owing to its symbiotic nature, the coral-dwelling worm snail of the present study cannot be confused with previously reported Caribbean species, such as the reef-building Petaloconchus varians (d'Orbigny, 1839) in Venezuela [5] and Brazil [25]. The invasive vermetid Eualetes tulipa (Chenu, 1843) has also been recorded in the West Atlantic and the Caribbean, but its operculum is much darker than that of our specimens and it has not been reported as a coral symbiont but as colonies on rock and artificial substrate $[26,27]$. Dendropoma corrodens (d'Orbigny, 1841) is a small worm snail species (ca. $1 \mathrm{~cm}$ long), known from the Caribbean and the mid-Atlantic, which forms aggregations on dead coral substrate [26].

Several snail tubes were covered by algae and surrounded by faecal pellets (Figure 3). Many were surrounded by dead coral tissue (Figure 3B,C,E) or attached to dead coral next to the host's margin (Figure 3A). A few snails showed remnants of mucus webs (Figures $2 \mathrm{~A}$ and $3 \mathrm{D}, \mathrm{F})$. In some corals, the snail tube was killing the polyps underneath and did not become overgrown by coral tissue (Figure 2C,D; Supplementary Materials Figures S17 and S19). In other ones no damage was observed, such as in Cladopsammia manuelensis, Eusmilia fastigiata, Madracis auretenra, M. decactis and Millepora alcicornis (Figure 2A,B; Supplementary 
Materials Figures S4 and S7-S9). Cladopsammia manuelensis has recently been discovered as a shallow-water coral in the Caribbean $[28,29]$.
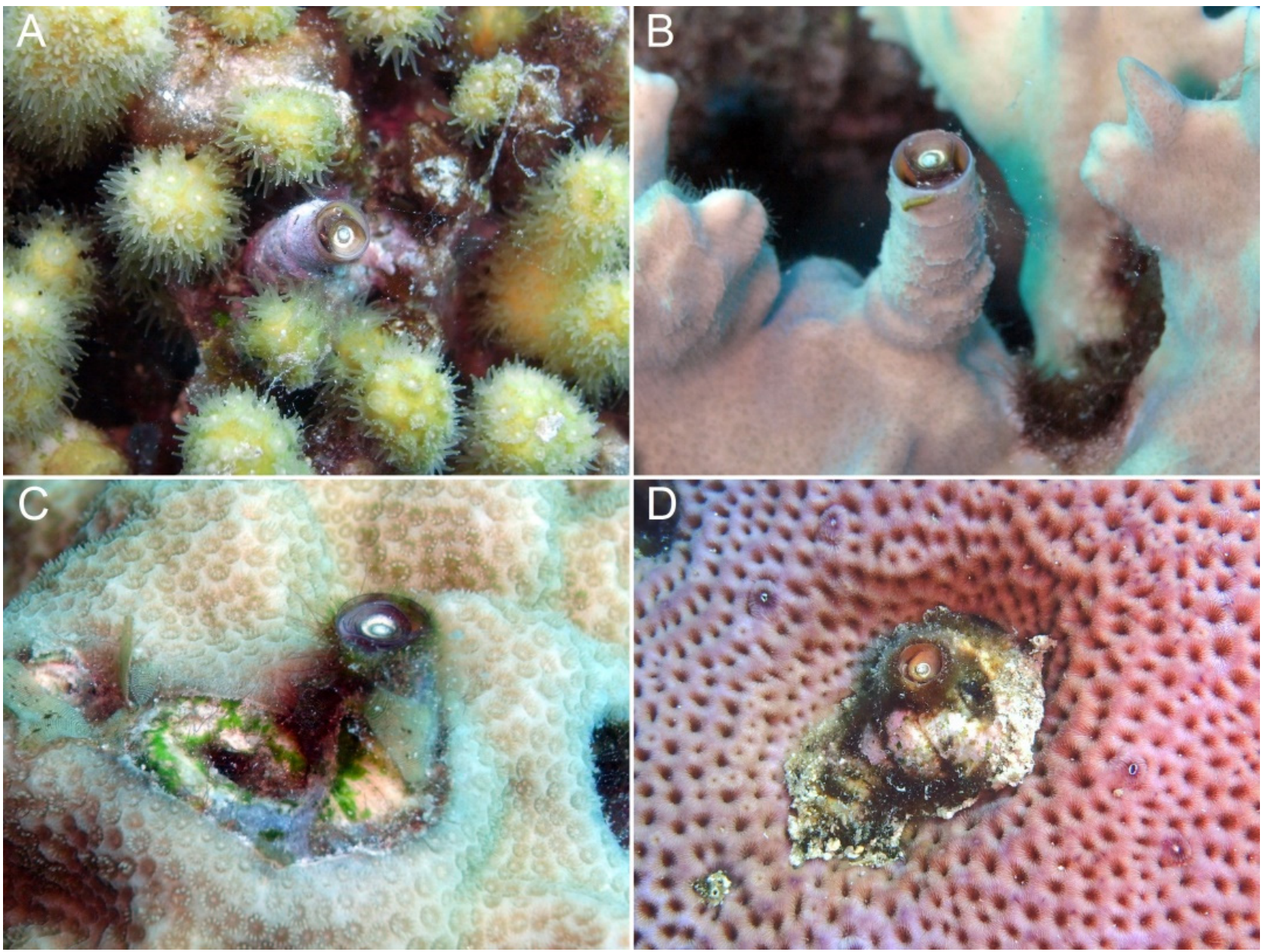

Figure 2. Worm snails (Petaloconchus sp.) hosted by the branching corals Madracis auretenra (A) and Millepora alcicornis (B), and the massive corals Porites astreoides (C) and Siderastrea siderea (D). The snail tube in M. alcicornis is entirely overgrown by the coral (B), whereas the snails in both massive corals have caused considerable damage to their hosts (C,D). Tube diameter: ca. $4 \mathrm{~mm}$.

\section{Discussion}

Since Caribbean coral-dwelling vermetids previously were not recognized in the scientific literature, they may have become introduced recently or they may have been overlooked. The tubes of the snails can be confused with those of polychaete worms of the serpulid genus Spirobranchus Blainville, 1818, which are common in the Caribbean, where they have a wide host range [30]. Both groups, coral-dwelling worm snails and serpulid worms, have their tubes partially embedded in the coral skeleton and both possess an operculum that is used to close the tube for the protection of soft bodyparts [2,31]. Spirobranchus worms are eye-catching because of their high densities and colorful, twin-conispiral branchiae [31,32]. Vermetid snails, on the other hand, use transparent mucus nets to catch food (Figure 3D,F) [33-35], which makes them less remarkable (Supplementary Materials Figure S19). 


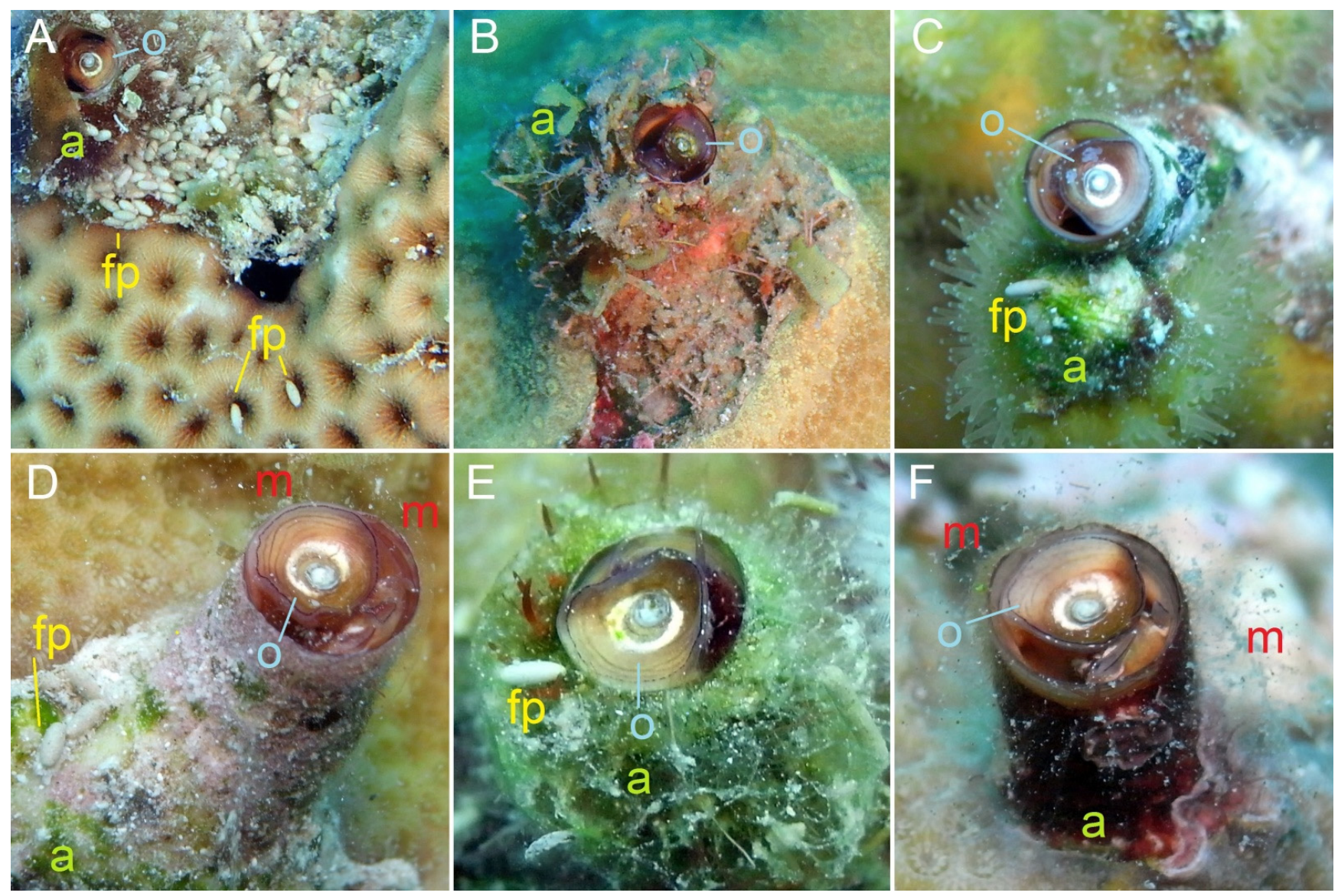

Figure 3. Close-up images of worm snails (Petaloconchus sp.) and their hosts: Siderastrea siderea (A), Porites astreoides (B,D-F), and Madracis auretenra $(\mathbf{C})$. The tubes are partly or entirely overgrown or surrounded by green and red algae (a). The operculum (o) appears to be tapering towards one side because of the margins being turned upwards next to the tentacles. Some worms show remnants of mucus nets (m). Faecal pellets are common around the tubes (fp). Tube diameter: ca. $4 \mathrm{~mm}$.

The habitat of Petaloconchus sp. resembles that of $P$. keenae, which has been reported as an associate of the Indo-Pacific coral genera Porites, Montipora, and Pavona at the Hawaiian islands [21], and possibly as Petaloconchus cf. keenae living in corals at Kwajalein Atoll in the Marshall Islands [36]. It is therefore reasonable to speculate that the coral-associated Petaloconchus sp. in the southern Caribbean is the same species and that it has been introduced from the tropical Indo-Pacific. As long as its identity cannot be confirmed by molecular analyses and morphological studies of the radula, protoconch, egg capsules, and coloration of shell and body [21,22], we consider the present species to be cryptogenic in the southern Caribbean. An earlier presence of such Caribbean worm snails could be verified with the help of coral collections in natural history museums [37]. Most museum collections of stony corals consist of dry specimens, but remnants of vermetid shells may still be present and recognizable.

Considering the poor knowledge of Petaloconchus sp. in the Caribbean, it is relevant to know of possible natural enemies that may be able to remove evidence of coral-dwelling vermetids. The carpiliid crab Carpilius convexus (Forskål, 1775) has been reported to prey on the vermetid Ceraesignum maximum in the Red Sea by breaking its shell and the coral in which it lives [38]. A possible predator of Petaloconchus sp. would therefore be Carpilius corallinus Herbst, 1783, which has been observed to crush large tubes of serpulid worms and also parts of the host coral [39].

The host-coral range in the present study (21 species) is more extensive than recorded for any other coral-associated vermetid. The host ranges of the Indo-Pacific vermetids $C$. 
maximum and P. keenae (mentioned above) are based on miscellaneous records and might be much larger in reality. Previous field surveys specifically targeting host-coral ranges (and prey preferences) of gastropod families and genera also yielded various additional host records and showed that some species are very host-specific, e.g., Leptoconchus [40] and Epitoniidae [41], and that others are generalists, such as some species of Coralliophila [42] and Drupella $[43,44]$. Research on coral-dwelling nudibranchs, such as the well-camouflaged Phestilla spp., also demonstrates that an ongoing search for possible hosts results in new association records and species discoveries [45-47].

The occurrence of coral injuries (dead coral surface and shells overgrowing coral polyps) suggests that the snails are harmful to their hosts, which is relevant for coral reef conservation $[48,49]$. It is possible that coral polyps are killed by the snail's mucus webs (Figures 2A and 3D,F), which may smother and even poison them if the mucus is toxic, as reported for Ceraesignum maximum [50]. The occurrence of turf algae on the shells is expected to increase damage to the hosts, as observed in Spirobranchus tubes overgrowing coral polyps [31,32]. Future field research with a focus on reef-dwelling vermetids will likely result in more information on their densities and additional host records. Molecular analyses may reveal the actual identity of the present species and its native range, and also whether cryptic speciation has taken place across the various host corals.

Supplementary Materials: The following supporting information can be downloaded at: https: / / www.mdpi.com/article/10.3390/d14030196/s1, Supplementary S1: photographic host records of Petaloconchus sp.: Figure S1: Agaricia agaricites at Bonaire (2019); Figure S2: Agaricia humilis at Curaçao (2021); Figure S3: Agaricia lamarcki at Curaçao (2021); Figure S4: Cladopsammia manuelensis at Curaçao (2017); Figure S5: Colpophyllia natans at Curaçao (2021); Figure S6: Diploria labyrinthiformis at Curaçao (2021); Figure S7: Eusmilia fastigiata at Curaçao (2014); Figure S8: Madracis auretenra at Curaçao (2021); Figure S9: Madracis decactis at Bonaire (2019); Figure S10: Madracis senaria at Curaçao (2021); Figure S11: Madracis senaria at Bonaire (2019); Figure S12: Meandrina meandrites at Curaçao (2021); Figure S13: Millepora alcicornis at Curaçao (2021); Figure S14: Millepora complanata at Curaçao (2015); Figure S15: Montastraea cavernosa at Bonaire (2019); Figure S16: Orbicella annularis at Bonaire (2019); Figure S17: Orbicella faveolata at Curaçao (2021); Figure S18: Orbicella franksi at Bonaire (2019); Figure S19: Porites astreoides at Curaçao (2021); Figure S20: Pseudodiploria strigosa at Curaçao (2021); Figure S21: Siderastrea siderea at Curaçao (2021); Figure S22: Stephanocoenia intersepta at Curaçao (2021); Figure S23: Unidentified dead coral at Curaçao (2021).

Author Contributions: Conceptualization, B.W.H. and R.J.v.d.S.; methodology, B.W.H., C.E.H., S.J.L.-D., R.J.v.d.S., A.S.-M., R.S., R.F.T.; validation, B.W.H.; formal analysis, B.W.H.; investigation, B.W.H., C.E.H., S.J.L.-D., R.J.v.d.S., A.S.-M., R.S., R.F.T.; resources, B.W.H., C.E.H., S.J.L.-D., R.J.v.d.S., A.S.-M., R.S., R.F.T.; data curation, B.W.H., C.E.H., S.J.L.-D., R.J.v.d.S., A.S.-M., R.S., R.F.T.; writingoriginal draft preparation, B.W.H.; writing-review and editing, B.W.H., C.E.H., S.J.L.-D., R.J.v.d.S., A.S.-M., R.S., R.F.T.; visualization, B.W.H., C.E.H., S.J.L.-D., R.J.v.d.S., A.S.-M., R.S., R.F.T.; supervision, B.W.H.; project administration, B.W.H.; funding acquisition, B.W.H., C.E.H., S.J.L.-D., R.J.v.d.S., A.S.-M., R.S., R.F.T. All authors have read and agreed to the published version of the manuscript.

Funding: The field research at Curaçao was funded by the Alida M. Buitendijk Fund, the Jan-Joost ter Pelkwijk Fund, the Holthuis Fund, and the Dutch Research Council (NWO) Doctoral Grant for Teachers Programme (nr. 023.015.036). Fieldwork at Bonaire was supported by the World Wildlife Fund (WWF) Netherlands. The Treub Maatschappij (Society for the Advancement of Research in the Tropics) funded research at both Bonaire and Curaçao.

Institutional Review Board Statement: Not applicable.

Data Availability Statement: Data sharing not applicable.

Acknowledgments: We are grateful to the funding agencies mentioned above. We thank Rudiger Bieler (Field Museum of Natural History, Chicago) for the identification of the worm snail. We thank the staff of CARMABI (Curaçao) and the Dive Shop for their hospitality and assistance during the fieldwork. BWH is also grateful to Stichting Nationale Parken Bonaire (STINAPA), Dutch Caribbean Nature Alliance (DCNA) and Dive Friends (Bonaire) for logistical support at Bonaire, and to the Caribbean Netherlands Science Institute (CNSI), St. Eustatius National Parks Foundation (STENAPA), 
and Scubaqua Dive Center, for facilitating research in St. Eustatius. We also want to thank two anonymous reviewers for their constructive comments, which helped us to improve the manuscript.

Conflicts of Interest: The authors declare no conflict of interest.

\section{References}

1. Schiaparelli, S.; Albertelli, G.; Cattaneo-Vietti, R. Phenotypic plasticity of Vermetidae suspension feeding: A potential bias in their use as biological sea-level indicators. Mar. Ecol. 2006, 27, 44-53. [CrossRef]

2. Morton, J.E. The evolution of vermetid gastropods. Pac. Sci. 1955, 9, 3-15.

3. Schiaparelli, S.; Cattaneo-Vietti, R. Functional morphology of the vermetid feeding tubes. Lethaia 1999, 32, 41-46. [CrossRef]

4. Jones, B.; Hunter, I.G. Vermetid buildups from Grand Cayman, British West Indies. J. Coast. Res. 1995, 11, 973-983. [CrossRef]

5. Weinberger, V.P.; Miloslavich, P.; Machordom, A. Distribution pattern, reproductive traits, and molecular analysis of two coexisting vermetid gastropods of the genus Petaloconchus: A Caribbean endemic and a potential invasive species. Mar. Biol. 2010, 157, 1625-1639. [CrossRef]

6. Montagna, P.; Silenzi, S.; Devoti, S.; Mazzoli, C.; McCulloch, M.; Scicchitano, G.; Taviani, M. Climate reconstructions and monitoring in the Mediterranean Sea: A review on some recently discovered high-resolution marine archives. Rend. Fis. Acc. Lincei 2008, 19, 121-140. [CrossRef]

7. Vescogni, A.; Bosellini, F.R.; Reuter, M.; Brachert, T.C. Vermetid reefs and their use as palaeobathymetric markers: New insights from the Late Miocene of the Mediterranean (Southern Italy, Crete). Palaeogeogr. Paleoclimatol. Paleoecol. 2008, 267, 89-101. [CrossRef]

8. Furlani, S.; Vaccher, V.; Antonioli, F.; Agate, M.; Biolchi, S.; Boccali, C.; Busetti, A.; Caldareri, F.; Canziani, F.; Chemello, R.; et al. Preservation of modern and MIS 5.5 erosional landforms and biological structures as sea level markers: A matter of luck? Water 2021, 13, 2127. [CrossRef]

9. Bieler, R. Mörch's worm-snail taxa (Caenogastropoda: Vermetidae, Siliquariidae, Turritellidae). Am. Malacol. Bull. 1996, 13, $23-35$.

10. Scott, P.J.B. Associations between corals and macro-infaunal invertebrates in Jamaica, with a list of Caribbean and Atlantic coral associates. Bull. Mar. Sci. 1987, 40, 271-286.

11. Perry, C.T. Macroborers within coral framework at Discovery Bay, north Jamaica: Species distribution and abundance, and effects on coral preservation. Coral Reefs 1998, 17, 277-287. [CrossRef]

12. Lewis, J.B. Biology and ecology of the hydrocoral Millepora on coral reefs. Adv. Mar. Biol. 2000, 50, 1-55. [CrossRef]

13. Hoeksema, B.W.; van Beusekom, M.; ten Hove, H.A.; Ivanenko, V.N.; van der Meij, S.E.T.; van Moorsel, G.W.N.M. Helioseris cucullata as a host coral at St. Eustatius. Dutch Caribbean. Mar. Biodivers. 2017, 47, 71-78. [CrossRef]

14. Colgan, M.W. Growth rate reduction and modification of a coral colony by a vermetid mollusc Dendropoma maxima. In Proceedings of the 5th International Coral Reef Congress, Tahiti, 27 May-1 June 1985; Volume 6, pp. 205-210.

15. Scaps, P.; Denis, V. Can organisms associated with live scleractinian corals be used as indicators of coral reef status? Atoll Res. Bull. 2008, 566, 1-18. [CrossRef]

16. Zvuloni, A.; Armoza-Zvuloni, R.; Loya, Y. Structural deformation of branching corals associated with the vermetid gastropod Dendropoma maxima. Mar. Ecol. Prog. Ser. 2008, 363, 103-108. [CrossRef]

17. Shima, J.S.; Osenberg, C.W.; Stier, A. The vermetid gastropod Dendropoma maximum reduces coral growth and survival. Biol. Lett. 2010, 6, 815-818. [CrossRef]

18. Shima, J.S.; Phillips, N.E.; Osenberg, C.W. Consistent deleterious effects of vermetid gastropods on coral performance. J. Exp. Mar Biol. Ecol. 2013, 439, 1-6. [CrossRef]

19. Brown, A.L.; Osenberg, C.W. Vermetid gastropods modify physical and chemical conditions above coral-algal interactions. Oecologia 2018, 186, 1091-1099. [CrossRef]

20. Barton, J.A.; Bourne, D.G.; Humphrey, C.M.; Hutson, K.S. Parasites and coral-associated invertebrates that impact coral health. Rev. Aquac. 2020, 12, 2284-2303. [CrossRef]

21. Hadfield, M.G.; Kay, E.A.; Gillette, M.U.; Lloyd, M.C. The Vermetidae (Mollusca: Gastropoda) of the Hawaiian Islands. Mar. Biol. 1972, 12, 81-98. [CrossRef]

22. Kelly, W.C., III. Three new vermetid gastropod species from Guam. Micronesica 2007, 39, 117-140.

23. Joshi, D.M.; Mankodi, P.C. The Vermetidae of the Gulf of Kachchh, western coast of India (Mollusca, Gastropoda). ZooKeys 2016, 555, 1-10. [CrossRef]

24. Barash, A.; Zenziper, Z. Structural and biological adaptations of Vermetidae (Gastropoda). Boll. Malacol. 1985, 21, 145-176.

25. Breves, A.; Széchy, M.T.M.; Lavrado, H.P.; Junqueira, A.O. Abundance of the reef-building Petaloconchus varians (Gastropoda: Vermetidae) on intertidal rocky shores at Ilha Grande Bay, southeastern Brazil. An. Acad. Bras. Ciências 2017, 89, 907-918. [CrossRef]

26. Miloslavich, P.; Klein, E.; Penchaszadeh, P. Gametogenic cycle of the tropical vermetids Eualetes tulipa and Dendropoma corrodens (Mollusca: Caenogastropoda: Vermetidae). J. Mar. Biol. Assoc. UK 2010, 90, 509-518. [CrossRef]

27. Spotorno-Oliveira, P.; Coutinho, R.; de Souza Tâmeg, F.T. Recent introduction of non-indigenous vermetid species (Mollusca, Vermetidae) to the Brazilian coast. Mar. Biodivers. 2018, 48, 1931-1941. [CrossRef] 
28. Hoeksema, B.W.; Hiemstra, A.F.; Vermeij, M.J.A. The rise of a native sun coral species on southern Caribbean coral reefs. Ecosphere 2019, 10, e02942. [CrossRef]

29. Hammerman, N.M.; Williams, S.M.; Veglia, A.J.; Garcia-Hernandez, J.E.; Schizas, N.V.; Lang, J.C. Cladopsammia manuelensis sensu Cairns, 2000 (Order: Scleractinia): A new distribution record for Hispaniola and Puerto Rico. Cah. Biol. Mar. 2021, 62, 1-10. [CrossRef]

30. Hoeksema, B.W.; ten Hove, H.A. The invasive sun coral Tubastraea coccinea hosting a native Christmas tree worm at Curaçao, Dutch Caribbean. Mar. Biodivers. 2017, 47, 59-65. [CrossRef]

31. Hoeksema, B.W.; Wels, D.; van der Schoot, R.J.; ten Hove, H.A. Coral injuries caused by Spirobranchus opercula with and without epibiotic turf algae at Curaçao. Mar. Biol. 2019, 166, 60. [CrossRef]

32. Hoeksema, B.W.; van der Schoot, R.J.; Wels, D.; Scott, C.; ten Hove, H.A. Filamentous turf algae on tube worms intensify damage in massive Porites corals. Ecology 2019, 100, e2668. [CrossRef] [PubMed]

33. Hughes, R.N.; Lewis, A. On the spatial distribution, feeding and reproduction of the vermetid gastropod Dendropoma maximum. J. Zool. 1974, 172, 531-547. [CrossRef]

34. Kappner, I.; Al-Moghrabi, S.M.; Richter, C. Mucus-net feeding by the vermetid gastropod Dendropoma maxima in coral reefs. Mar. Ecol. Prog. Ser. 2000, 204, 309-313. [CrossRef]

35. Kusama, Y.; Nakano, T.; Asakura, A. Mucus-net feeding behavior by the sessile gastropod Thylacodes adamsii (Gastropoda: Vermetidae). Publ. Seto Mar. Biol. Lab. 2021, 46, 55-69. [CrossRef]

36. Kwajalein Underwater: Petaloconchus cf keenae Hadfield \& Kay. 1972. Available online: http://www.underwaterkwaj.com/shell/ vermetid/Petaloconchus-cf-keenae.htm (accessed on 14 February 2022).

37. Hoeksema, B.W.; van der Land, J.; van der Meij, S.E.T.; van Ofwegen, L.P.; Reijnen, B.T.; van Soest, R.W.M.; de Voogd, N.J. Unforeseen importance of historical collections as baselines to determine biotic change of coral reefs: The Saba Bank case. Mar. Ecol. 2011, 32, 135-141. [CrossRef]

38. Shlesinger, T.; Akkaynak, D.; Loya, Y. Who is smashing the reef at night? A nocturnal mystery. Ecology 2021, 102, e03420. [CrossRef]

39. Muller, E.; de Gier, W.; ten Hove, H.A.; van Moorsel, G.W.N.M.; Hoeksema, B.W. Nocturnal predation of Christmas tree worms by a Batwing coral crab at Bonaire (Southern Caribbean). Diversity 2020, 12, 455. [CrossRef]

40. Gittenberger, A.; Gittenberger, E. Cryptic, adaptive radiation of endoparasitic snails: Sibling species of Leptoconchus (Gastropoda: Coralliophilidae) in corals. Org. Divers. Evol. 2011, 11, 21-41. [CrossRef]

41. Gittenberger, A.; Hoeksema, B.W. Habitat preferences of coral-associated wentletrap snails (Gastropoda: Epitoniidae). Contrib. Zool. 2013, 82, 1-25. [CrossRef]

42. Potkamp, G.; Vermeij, M.J.A.; Hoeksema, B.W. Genetic and morphological variation in corallivorous snails (Coralliophila spp.) living on different host corals at Curaçao, southern Caribbean. Contrib. Zool. 2017, 86, 111-144. [CrossRef]

43. Hoeksema, B.W.; Scott, C.; True, J.D. Dietary shift in corallivorous Drupella snails following a major bleaching event at Koh Tao, Gulf of Thailand. Coral Reefs 2013, 32, 423-428. [CrossRef]

44. Moerland, M.S.; Scott, C.M.; Hoeksema, B.W. Prey selection of corallivorous muricids at Koh Tao (Gulf of Thailand) four years after a major coral bleaching event. Contrib. Zool. 2016, 85, 291-309. [CrossRef]

45. Mehrotra, R.; Arnold, S.; Wang, A.; Chavanich, S.; Hoeksema, B.W.; Caballer, M. A new species of coral-feeding nudibranch (Mollusca: Gastropoda) from the Gulf of Thailand. Mar. Biodivers. 2020, 50, 36. [CrossRef]

46. Wang, A.; Conti-Jerpe, I.E.; Richards, J.L.; Baker, D.M. Phestilla subodiosus sp. nov. (Nudibranchia, Trinchesiidae), a corallivorous pest species in the aquarium trade. ZooKeys 2020, 909, 1-24. [CrossRef] [PubMed]

47. Yiu, S.K.F.; Chung, S.S.W.; Qiu, J.W. New observations on the corallivorous nudibranch Phestilla melanobrachia: Morphology, dietary spectrum and early development. J. Molluscan Stud. 2021, 87, eyab034. [CrossRef]

48. Stella, J.S.; Pratchett, M.S.; Hutchings, P.A.; Jones, G.P. Coral-associated invertebrates: Diversity, ecology importance and vulnerability to disturbance. Oceanogr. Mar. Biol. Ann. Rev. 2011, 49, 43-104.

49. Montano, S. The extraordinary importance of coral-associated fauna. Diversity 2020, 12, 357. [CrossRef]

50. Klöppel, A.; Brümmer, F.; Schwabe, D.; Morlock, G. Detection of bioactive compounds in the mucus nets of Dendropoma maxima, Sowerby 1825 (Prosobranch Gastropod Vermetidae, Mollusca). J. Mar. Biol. 2013, 2013, 283506. [CrossRef] 